\title{
Edmond Halley*
}

\section{By Dr. Allan Ferguson}

$\mathrm{T}$ $\mathrm{HE}$ contributions of Shoreditch to the advancement of science are neither many nor varied; the occasional visitor to that cabinetmaking region is usually drawn thither by the fame of the parish stocks and whipping-post, or of that oddly inscribed tombstone which marks Dr. John Gardner's "last and best bedroom". But the district has made one contribution of primary importance, for it was in the parish of St. Leonard's Shoreditch that Edmond Halley was born in 1656. Shoreditch was then a suburb of that pre-fire London of which so few traces remain. The London that Halley knew was a London cheerful, noisy and dirty, to modern eyes incredibly small, with narrow, fetid, kerbless streets and rat-ridden, overhanging houses; with a steep descent to the Fleet river, then practically an open sewer, where Holborn viaduct now stands; with an equally steep ascent to Tyburn along that via dolorosa, now called Oxford Street; with one ancient many-arched bridge joining the city to Southwark, its gateway crowned with frowning and blackened heads, its piers and starlings damming the river so effectively as to produce at certain stages of the tide several feet difference of level in the water above and below the bridge; with Whitehall still crossed by a Tudor gateway, and the banqueting house of Inigo Jones alive with recent memories of the royal execution.

The ghastly plague pit at Aldgate, hard by the Three Nuns hotel, comes clearly enough even now before the minds of those who turn eastwards from Houndsditch along the little alley that skirts St. Botolph's church, and swings southward through Church Row to join Aldgate. A Three Nuns' hostel still stands near the church, the graveyard of which is significantly raised some feet above the level of the surrounding streets. Pit, inn, church, and the vanished Pye Tavern "over against the end of Houndsditch" where an obscene crowd of roysterers was wont to gather and to jeer at the passing dead-cart must have been very vivid in the memory of Halley, who passed, apparently unscathed, through these fateful years. He was educated at St. Paul's School, under Dr. Thomas Gale, and at fifteen years of age was captain of the school. In 1673 he was admitted a student of Queen's College, Oxford, "having already acquired not only good skill in the Latin, Greek and Hebrew Tongues, but being also well acquainted in the Principles of Geometry and Astronomy, in which he ... so early distinguisht himself, that we find a Piece of His, called, Methodus directa et Geometrica cujus

" "Correspondence and Papers of Edmond Halley." Preceded by an unpublished Memoir of his Life by one of his Contemporaries, and the 'Éloge' by d'Ortous de Mairan. Arranged and Edited by Eugene Fairfleld MacPike. (History of Science Society Publications, New Series 2.) Pp. xiv $+300+9$ plates. (Oxford : Clarendon Press ;
London: Oxford University Press, 1932.) 21s. net. ope investigantur Aphelia, Excentricitantes, Proportionesque Orbitarum Planetareorum, absque supposita aqualitate Anguli motus ad alterum Ellipeos Focum, ab Astronomis hactenus usurpata, . . . publish't in the Philosophical Transactions for the Months of August and September, 1676." Kepler had, as we know, enunciated many years before this date his laws stating that the path of a planet is an ellipse, with the sun in one focus; and that the motion of the planet round the sun is not uniform, but is such that the line joining sun to planet sweeps out equal areas in equal times. It was assumed, and it is in fact nearly true, that the motion about the empty focus of the ellipse was exactly uniform; that Halley, at nineteen, should be able to attack critically such a problem shows that he was already highly skilled in the use of the imperfect mathematical apparatus of his day.

Halley did not stay long enough at Oxford to take his degree. His was one of those prescient characters that realises almost instinctively the direction in which knowledge is advancing, and which field it profits best to cultivate. His tastes lay in the direction of astronomy, and he well knew that trustworthy star-charts were one of the pressing needs of the day. But several explorers, Flamsteed and Hevelius in particular, had already set out to chart the northern stars, and Halley, now a skilled mathematician and observer, knew the advantages of a clear field; he therefore decided to make a beginning in the southern hemisphere.

Halley's father, a wealthy London tradesman, settled on his son an allowance of $£ 300$ a year, and in 1676, armed with "an excellent brass sextant of $5 \frac{1}{2}$ feet radius, with Telescopic Sights and indented Semicircles of the same Metal, and Screws for the ready bringing it into any Plane; a Quadrant of about 2 foot Radius, which he chiefly intended for observations to adjust his Clock; a good pendulum clock; and a Telescope of 24 feet; some lesser ones; and two Micrometers", Halley set sail for St. Helena, where he had decided to set up his observatory.

The climate of St. Helena proved to be very much what it was a century and a half later when the island became the scene of Napoleon's exile. Nevertheless, though the skies were cloudy and rain frequent, Halley stayed there for about a year ; and the title of the 'Southern Tycho' was given to him in virtue of his star catalogue, published in 1679 .

In this last-named year, Halley embarked upon another adventure. To-day it appears absurdly obvious that far greater accuracy in determining stellar positions is obtained by sighting a star through a telescope than by using the naked eye and the sighting rods in the manner of the older 
astronomers. This was not so obvious in 1679 ; ordinary pinhole sights were certainly crude, but Tycho, one of the great pioneers in exact measurement, had improved this type of sight almost beyond recognition. An example of his measurements may serve to show the accuracy attainable by the use of naked eyesights. Tycho, alive to the necessity for accurate charting, selected seven stars, the most important of these being $\alpha$ Arietis, as standard stars, the positions of which on the celestial sphere he determined with the highest possible accuracy. These measurements of position must, of course, be made with reference to some definite starting point, and it is the intersection of the sun's apparent yearly path in the heavens with the equator of the celestial sphere which determines the position of the Greenwich of the heavens. Tycho's task, therefore, was that of linking up the position of the sun with that of any one of the selected stars. This was done by means of an intermediary, Venus, visible both in the daytime and at night. Tycho determined the relative positions of the sun and Venus, and afterwards of Venus and one of the selected stars, making due allowance for the motion of Venus in the period intervening between the two observations. Some notion of Tycho's accuracy may be gleaned from the fact that the Right Ascension (the analogue of terrestrial longitude) of $\alpha$ Arietis was fixed by him at a mean value of $26^{\circ} 0^{\prime} 30^{\prime \prime}$, the modern estimate for the year 1585 being $26^{\circ} 0^{\prime} 45^{\prime \prime}$. Dreyer gives the probable errors of the positions of Tycho's standard stars as $\pm 24^{\prime \prime} \cdot 1$ in Right Ascension and $25^{\prime \prime} \cdot 9$ in Declination (when corrected for refraction).

With possibilities of consistency in observing indicated by figures such as these, it is not surprising that older observers, cognisant of the crudity of the new telescopic sights, should elect to continue to make their observations by the older methods. Foremost among them was Hevelius of Dantzig and, the better to make a critical comparison of the two methods, Halley visited Dantzig in 1679 . He was duly impressed with the skill displayed by Hevelius in the use of his instruments, and, in a letter to Flamsteed under date June 7, 1679, he says, after describing the equipment of Hevelius's observatory :". . . As to the distances measured by the Sextans, I assure you I was surpris'd to see so near an agreement in them, and had I not seen, I could scarce have credited the relation of any; Verily I have seen the same distance repeated several times without any fallacy agree to $10^{\prime \prime}$, and on Wednesday last I myself tryed what I could doe, and first I at the moveable sight, and the Printer at the fixt did observe the distance of Yed Ophiuchi from Lucida Aquilæ 55 $-19^{\prime}-00^{\prime \prime}$; then we removed the Index, and my Lord at the moveable sight and I at the fixt did observe the same $55^{\circ}-19^{\prime}-05^{\prime \prime}$, and you will find the same distance 6 times observed in Page 272 of ye fourth book of his Machina Coelestis, so that I dare no more doubt of his veracitye." Nevertheless,
Halley was too sagacious not to realise that ultimate victory lay with the users of telescopic sights. As for Hevelius, the writer of a memoir of Halley remarks that "the old Gentleman was too much rivetted to his Opinion of those he had so long and so successfully used; and had besides been too much sour'd by the manner in which Dr. Hooke had too freely treated his Labours to think of altering his method or opinion".

It is interesting to note that in a hitherto unpublished letter in the Royal Society's archives Halley, writing under date 1686 to Molyneux concerning "the state of the Controversy between $\mathrm{Mr}$. Hevelius and $\mathrm{Mr}$. Hook about Telescope Sights wherein I am so much concerned", remarks that this controversy "does, as Hevelius manages the matter, affect all those observers that use Telescope sights, and myself in particular, and it is our common concern to vindicate the truth from the aspersions of an old peevish gentleman, who would not have it believed that it is possible to do better than he has done".

Halley's next piece of sustained practical work lay in a study of the variation of the compass. Here again we see illustrated his habit of seizing on a pioneer piece of work, and rounding it off neatly and thoroughly. Provided with a vessel, the Paramour Pink-did ever other astronomer sail in so romantically named a ship ?-Halley set sail in 1698. True to her romantic name, the ship was the scene of a mutiny, and Halley was forced to return to England. A mutinous lieutenant duly cashiered, Halley again set sail, this time accompanied by a consort, and returned the possessor of a unique mass of data, which he exhibited graphically after the modern manner, being in this matter again a pioneer.

Halley was appointed Savilian professor at Oxford in 1703, and in 1719, promoted to the position of Astronomer Royal, this indefatigable worker found himself in command of an observatory almost unprovided with instruments. He refurnished the observatory and optimistically set out at the age of sixty-three on an eighteen year cycle of lunar observations. He was, as ever, fortunate in his plan which he lived to complete, dying at the patriarchal age of eighty-five years. His interest in cometary orbits led him to study in detail the paths of several of these bodies and he concluded that the comets seen in 1531, 1607, and 1682 were not three separate bodies, but one and the same. The matter is, of course, considerably more complex than is indicated by a mere comparison of periods. Halley had, with immense labour, worked out the elements of the orbits of twenty-four comets. Three of these-those just mentioned-were sufficiently similar to make their identity probable, and this possibility was strengthened by the records of cometary appearances in 1305,1380 , and 1456. Nevertheless, the variations in the periods, and the differences in the inclinations of the orbits, amounting to as much as a degree, made recognition of their identity by no means certain. Halley was, however, too good a 
Newtonian not to recognise that irregularities might be introduced by the gravitational pull of the giant Jupiter and, taking due cognisance of this, he ventured on his prophecy. "Quo-circa," says he, "si secundum predicta nostra redierit iterum circa annum 1758, hoc primum ab homine Anglo inventum fuisse non inficiabitur acqua posteritas." This prediction of its return in 1758, and its reappearance on Christmas Day of that year, near upon twenty years after Halley has been laid to rest in Lee Churchyard, is one of the dramas of the eighteenth century.

Halley, too, first showed from a comparison of ancient and modern observations that Aldebaran, Arcturus and Sirius had 'proper motions'.

Remarkable, however, as may be the sum of these achievements, his place in the history of the development of astronomical science depends largely on his friendship with Newton and on his connexion with the Royal Society. He was elected a member of that body in 1678, and in 1685, when one Mr. Aston resigned his position as secretary in something of a passion, the Council, in order to avoid future contretemps, decided to appoint a paid clerk who "shall be a single man without children .. . shall be master of the English, French and Latin tongues, . . . shall be able to write a fair and legible hand, and shall be completely seen in the Mathematics and Experimental Philosophy". His duties were carefully defined, and his emoluments fixed at $£ 50$ per annum at least, with a lodging in "the College where the Society meeteth". Halley was appointed to the position after a contested election.

About this period the inverse square law of gravitation was in the minds of many astronomers. Kepler had laid the foundations in the statements that :-

(a) The planets move in ellipses having the sun in one focus :

(b) The radius vector sweeps out equal areas in equal times; and

(c) For different planets, the squares of the periodic times are proportional to the cubes of their distances from the sun.

It is not a very difficult matter to deduce the inverse square law from Kepler's third statement, and Hooke, Halley and Wren had each, apparently, accomplished this feat. But the inverse problemgiven the law of force, what will be the path of a planet?-proved too much for all of them. In a well-known letter from Halley to Newton we find the statement that "in January 1683-4 I, having from the consideration of the sesquialterate proportion of Kepler, concluded that the centripetal force decreased in the proportions of the squares of the distances reciprocally, came on Wednesday to town (from Islington), where I met with Sir Christopher Wren and Mr. Hooke and falling in discourse about it, Mr. Hooke affirmed that upon that principle all the laws of the celestial motions were to be demonstrated, and that he himself had done it". In the same letter he chronicles an offer made by Wren in a sporting spirit which we do not usually associate with his name. We read that "Sir Christopher, to encourage the enquiry said that he would give $\mathrm{Mr}$. Hooke some two months' time to bring him a convincing demonstration thereof, and besides the honour, he of us that did it should have from him the present of a book of forty shillings. Mr. Hooke then said he had it, but that he would conceal it for some time, that others trying and failing might know how to value it when he should make it public. However, I remember that Sir Christopher was little satisfied that he could do it, and though Mr. Hooke then promised to show it him, I do not find that in that particular he has been so good as bis word".

It was Halley who took the problem to Newton, to find that Newton had long ago solved this and other problems of planetary motion, and it was Halley's enthusiasm that overcame Newton's constitutional aversion to publication, and drove him to put forward his views in connected form. On April 28, 1686, Dr. Vincent laid before the Royal Society the MS. of the first book of the "Principia", and on May 19 the Society resolved that "Mr. Newton's Philosophice Naturalis Principia Mathematica be printed forthwith in quarto in a fair letter". On June 2 we hear a different note; the Council orders that "Mr. Newton's book be printed, and that Mr. Halley undertake the business of looking after it and printing it at his own charge" ; and Halley undertakes the task.

The Society was, in fact, in financial straits. It had, some time before, published "Willoughby de Historia Piscium", doubtless a learned volume, and one which then excited as much attention as a similar volume would do to-day. The Society made desperate efforts to minimise its loss, and the phrase "books of fishes" recurs in the Council minutes of the period like "the owercome $o$ ' a sang". The salaries of their officers fell into arrears, and the Council resolved to pay the unlucky philosophers in "books of fishes". Halley was agreeable; Hooke more cautiously desired six months time to consider the acceptance of such payment! Again, when the Society asked Halley to undertake the measurement of a degree of longitude, it was resolved that he "be given $£ 50$, or fifty books of fishes".

Newton, who could on occasion show what in a lesser man would be called peevishness, did not make Halley's task any easier by desiring to suppress the MS. of the third book of the "Principia", on hearing that Hooke was putting forward claims to priority. But Halley's perseverance triumphed over all difficulties and on July 5, 1686, the book received the Imprimatur of the then president, Samuel Pepys; it was published about the middle of 1687 .

Such is, in bare outline, the history of Halley's share in the publication of the "Principia". Rigaud does not put it any too high when he writes of "the immense obligation which the world owes . . to Halley, without whose great zeal, able 
management, unwearied patience, scientific attainments, and disinterested generosity, the Principia might never have been published".

The book before us does not call for detailed review. It is a model of its kind, and, while not a life of Halley, it brings together a mass of material which, interesting in itself, should prove of immense value to any future biographer of Halley. The volume contains a memoir, possibly written by Martin Folkes, an éloge by de Mairan, a chronological list of Halley's correspondence, and a large quantity of hitherto unprinted letters and papers arranged in order of date. An appendix of about a hundred pages is concerned with a valuable series of Halleiana. Scholarly, relatively inexpensive, and well produced, the book should find a place on the shelves of every serious student of astronomy.

\section{Recent Radio Research}

$\mathrm{T}$ HE Department of Scientific and Industrial Research has recently issued the report of the Radio Research Board for the year 1931,* summarising work carried out during the year. The investigations described are concerned mainly with the fundamental study of the electrical state of the upper atmosphere and its influence on the propagation of radio waves of all frequencies; the principles and improvements of method of radio direction-finding; the study of atmospherics from the point of view of radio communications and meteorology ; the development of radio frequency standards; and the improvement of electrical measurements at high frequencies. This work is carried out mainly at the Radio Research Station, Slough, and at the National Physical Laboratory, Teddington, but a certain amount of research has also been fostered at universities.

The study of the ionisation of the atmosphere and its influence on the propagation of radio waves has been continued both by the frequencychange method which was originated in Great Britain by Prof. E. V. Appleton, and also by the pulseemission or group-retardation method, first developed by G. Breit and M. A. Tuve in the United States. To assist in this investigation, which includes the systematic collection of data on the electrical properties of the upper atmosphere, a special transmitting installation has been designed and is in course of construction at the National Physical Laboratory. Concurrently with the experimental work, a theoretical analysis is being made of the effect of the upper atmosphere on radio waves, and the mathematical formulæ are being evaluated numerically for typical cases, so that the results can be used by the practical radio engineer. In all this work the effect of the earth's magnetic field is being studied, the necessity for this having been confirmed in an interesting manner in the year under review by experiments carried out in the southern hemisphere under the Australian Radio Research Board.

The report describes also the extension of the study of wave propagation to wave-lengths of less than 10 metres. In the first instance, the transmission of these ultra-short waves along the earth's surface has been investigated, and from the resulting measurements, values of the effective

* Department of Scientific and Industrial Research. Report of the Radio Research Board for the Year 1931. Pp. iv + 123. (London: H.M. Stationery Office, 1932.) 2s, net. conductivity and dielectric constant of the earth have been obtained by wave-lengths between $1 \cdot 6$ and 10 metres. In addition, experiments have been carried out on a wave-length of 5.5 metres over a distance of 44 miles. In these experiments the absence of any downcoming radiation from the upper atmosphere was clearly indicated, and it was apparent that only the direct or ground waves were effective in securing communication, although the reception obtained was definitely not confined to the rectilinear or so-called 'optical' path between transmitter and receiver. Certain diurnal variations were found on hot, sunny days which were not experienced on dull, autumn days. The theoretical and practical investigation of the whole subject is being continued. Progress is also recorded in the study of improved means for generating electron oscillations giving rise to wave-lengths of less than 1 metre.

The report indicates that considerable progress has been made towards the development of the perfect direction-finder for medium wave-lengths, free from errors caused by downcoming waves occurring mostly at night. The behaviour of direction-finders on shorter wave-lengths is being studied, and the application of the cathode ray oscillograph to a direct-reading instantaneous direction-finder has met with considerable success. This is undoubtedly due to the large amount of experience previously obtained in the use of these instruments in the study of atmospherics at the Radio Research Station.

In the present crowded state of the ether, it is specially important that every radio station should accurately maintain its allotted wavelength or frequency. The precise measurement of frequency, therefore, has become of great practical importance. The primary national standard of frequency is maintained at the National Physical Laboratory, and, as the report explains, is based on a tuning-fork maintained in continuous and steady vibration. The rate of vibration of the standard tuning-fork is now directly referred to that of an astronomical clock by an electrical arrangement, and can be obtained accurately to within one part in ten million. Experiments are in progress to determine the shortperiod constancy of the fork, that is, the constancy for one or two minutes at a time. It is not easy to compare frequencies to an accuracy of one part 